Keywords: DWPF, fissile, SB6, WAPS, Density

Retention: Permanent

\title{
EVALUATION OF GLASS DENSITY TO SUPPORT THE ESTIMATION OF FISSILE MASS LOADINGS FROM IRON CONCENTRATIONS IN SB6 GLASSES
}

T.B. Edwards

D.K. Peeler

December 2010

Savannah River National Laboratory Savannah River Nuclear Solutions Aiken, SC 29808

Prepared for the U.S. Department of Energy under contract number DE-AC09-08SR22470.

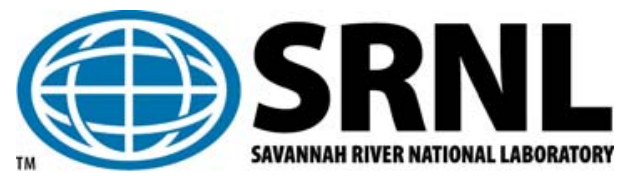




\section{DISCLAIMER}

This work was prepared under an agreement with and funded by the U.S. Government. Neither the U.S. Government or its employees, nor any of its contractors, subcontractors or their employees, makes any express or implied:

1. warranty or assumes any legal liability for the accuracy, completeness, or for the use or results of such use of any information, product, or process disclosed; or

2. representation that such use or results of such use would not infringe privately owned rights; or

3. endorsement or recommendation of any specifically identified commercial product, process, or service.

Any views and opinions of authors expressed in this work do not necessarily state or reflect those of the United States Government, or its contractors, or subcontractors.

\section{Printed in the United States of America}

\section{Prepared for}

U.S. Department of Energy 


\section{REVIEWS AND APPROVALS}

\section{AUTHORS:}

T.B. Edwards, Applied Computational Engineering and Statistics

Date

D.K. Peeler, Process Technology Programs

Date

TECHNICAL REVIEWS:

K.M. Fox, Process Technology Programs

Date

E.P. Shine, Applied Computational Engineering and Statistics

Date

APPROVALS:

C. C. Herman, Manager, Process Technology Programs

Date

S. L. Marra, Manager,

Date

Environmental \& Chemical Process Technology Research Programs

J. E. Occhipinti, Manager

Date

Waste Solidification Engineering 


\section{TABLE OF CONTENTS}

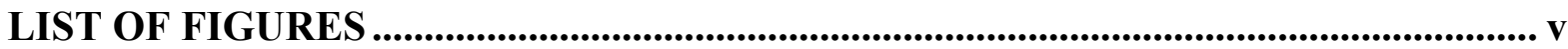

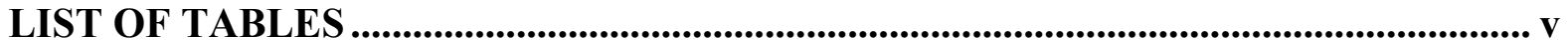

LIST OF ACRONYMS ........................................................................................................... vi

EXECUTIVE SUMMARY .......................................................................................... vii

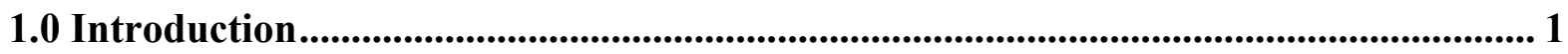

2.0 Experimental: SB6 Glass Density Determination ........................................................... 2

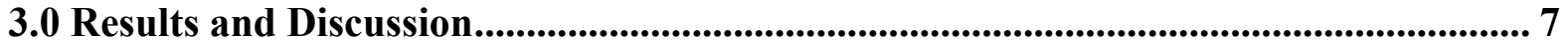

4.0 Summary ................................................................................................................................ 13

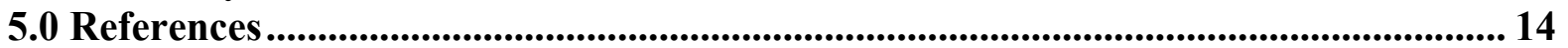




\section{LIST OF FIGURES}

Figure 1. Densities by Glass ID Grouped by \%WL and Type of Sludge Composition.

Figure 2. Density as a Function of Waste Loading for the Nominal Frit 418 - SB6 Variability Study Glasses.

Figure 3. Histogram and Descriptive Statistics for the Densities of SB6 VS Glasses at WL of 36\%.

\section{LIST OF TABLES}

Table 1. Target Glass Compositions for SB6 Variability Study Glasses (wt\%).

Table 2. Target Glass Compositions for the Supplemental $\mathrm{ThO}_{2}$-Based SB6 Variability Study Glasses (wt\%).

Table 3. Measured Densities of Frit 418 - SB6 Variability Study Glasses.

Table 4. Average Measured Densities of Frit 418 - SB6 Glasses.

Table 5. Predicted Densities as a Function of WL for the Linear Fit and 99/99 UTL. 


\section{LIST OF ACRONYMS}

$\begin{array}{ll}\text { DOE-SR } & \text { Department of Energy - Savannah River } \\ \text { DWPF } & \text { Defense Waste Processing Facility } \\ \text { LA } & \text { License Application } \\ \text { NIST } & \text { National Institute of Standards and Technology } \\ \text { RMSE } & \text { Root Mean Square Error } \\ \text { SB5 } & \text { Sludge Batch 5 } \\ \text { SB6 } & \text { Sludge Batch 6 } \\ \text { SME } & \text { Slurry Mix Evaporator } \\ \text { SRNL } & \text { Savannah River National Laboratory } \\ \text { SRR } & \text { Savannah River Remediation } \\ \text { UTL } & \text { Upper Tolerance Limit } \\ \text { WAPS } & \text { Waste Acceptance Product Specifications } \\ \text { WL } & \text { Waste Loading }\end{array}$




\section{EXECUTIVE SUMMARY}

The Department of Energy - Savannah River (DOE-SR) previously provided direction to Savannah River Remediation (SRR) to maintain fissile concentration in glass below $897 \mathrm{~g} / \mathrm{m}^{3}$. In support of the guidance, the Savannah River National Laboratory (SRNL) provided a technical basis and a supporting Microsoft ${ }^{\circledR}$ Excel ${ }^{\circledR}$ spreadsheet for the evaluation of fissile loading in Sludge Batch 5 glass based on the Fe concentration in glass as determined by the measurements from the Slurry Mix Evaporator (SME) acceptability analysis. SRR has since requested that SRNL provide the necessary information to allow SRR to update the Excel spreadsheet so that it may be used to maintain fissile concentration in glass below $897 \mathrm{~g} / \mathrm{m}^{3}$ during the processing of Sludge Batch 6 (SB6).

One of the primary inputs into the fissile loading spreadsheet includes a bounding density for SB6based glasses. Based on the measured density data of select SB6 variability study glasses, SRNL recommends that SRR utilize the 99/99 Upper Tolerance Limit (UTL) density value at 38\% WL $\left(2.823 \mathrm{~g} / \mathrm{cm}^{3}\right)$ as a bounding density for SB6 glasses to assess the fissile concentration in this glass system. That is, the $2.823 \mathrm{~g} / \mathrm{cm}^{3}$ is recommended as a key (and fixed) input into the fissile concentration spreadsheet for SB6 processing. It should be noted that no changes are needed to the underlying structure of the Excel based spreadsheet to support fissile assessments for SB6. However, SRR should update the other key inputs to the spreadsheet that are based on fissile and Fe concentrations reported from the SB6 Waste Acceptance Product Specification (WAPS) sample. 


\subsection{INTRODUCTION}

Based on analyses included in the Yucca Mountain Project License Application (LA), the Department of Energy - Savannah River (DOE-SR) gave direction to Savannah River Remediation (SRR) to maintain fissile concentration in glass below $897 \mathrm{~g} / \mathrm{m}^{3}$ for processing Sludge Batch 5 (SB5). The Savannah River National Laboratory (SRNL) provided a technical basis and a supporting Microsoft ${ }^{\circledR}$ Excel ${ }^{\circledR}$ spreadsheet for the evaluation of fissile loading in SB5 glass based on the Fe concentration in glass as determined by the measurements from the Slurry Mix Evaporator (SME) acceptability analysis (Edwards and Peeler 2009). SRR has since requested that SRNL provide the necessary information to allow SRR to update the Excel ${ }^{\circledR}$ spreadsheet so that it may be used to maintain fissile concentration in glass below $897 \mathrm{~g} / \mathrm{m}^{3}$ during the processing of Sludge Batch 6 (SB6). ${ }^{1}$ The necessary information to allow for these updates is: (1) information from the SB6 Waste Acceptance Product Specifications (WAPS) sample such as fissile:Fe concentration (Bannochie 2010), and (2) a bounding density for SB6 glasses. ${ }^{2}$ Once the inputs to the Excel spreadsheet have been updated to reflect the information for SB6, then the only other input to the spreadsheet that is needed to determine the fissile concentration for the glass anticipated by the processing of a SME batch is the Fe concentration as determined by the analysis of SME samples for each process batch.

The purpose of this technical report is to present the density measurements that were determined for the SB6 variability study glasses and to conduct a statistical evaluation of these measurements to provide a bounding density value that may be used as input to the Excel ${ }^{\circledR}$ spreadsheet to be employed by SRR to maintain the fissile concentration in its SB6 glass below $897 \mathrm{~g} / \mathrm{m}^{3}$. It should be noted that no changes are needed to the underlying structure of the Excel® based spreadsheet to support fissile assessments for SB6.

\footnotetext{
${ }^{1}$ Electronic communication from JM Bricker to DK Peeler, May 25, 2010 requesting statistical estimation of fissile content in the SB6 WAPS glass. See WSRC-NB-2003-00041, Sludge Batch 6 Glass Variability Study, page 37 for more details. ${ }^{2}$ Electronic communication from JM Bricker to DK Peeler, May 25, 2010 requesting density measurements on the original and supplemental SB6 variability study glasses. See WSRC-NB-2003-00041, Sludge Batch 6 Glass Variability Study, page 37 for more details.
} 


\subsection{EXPERIMENTAL: SB6 GLASS DENSITY DETERMINATION}

Insight into the density of SB6 glasses was based on the glasses resulting from the Frit 418 - SB6 variability study and a supplemental study to assess the impact of $\mathrm{ThO}_{2}$ on the durability of SB6 glasses (Johnson and Edwards 2010). For the Frit 418 - SB6 variability study, seventeen glasses (referred to as SB6VS-01 through SB6VS-17) were selected based on the sludge projections used to support the recommendation of Frit 418 for SB6 processing (Fox 2010). Table 1 summarizes the targeted compositions of the initial Frit 418 - SB6 Variability Study glasses (SB6VS-01 through SB6VS-17). Five of the glasses (SB6VS-13 through SB6VS-17) are based on the centroid of the compositional region, spanning a waste loading (WL) range of 32 to $40 \%$. The remaining twelve glasses (SB6VS-01 through SB6VS-12) are based on extreme vertices (EVs) of the sludge region of interest for SB6 combined with Frit 418 at 36\% WL.

In addition to the seventeen SB6 variability study glass, five glasses (referred to as SB6VS-18 through SB6VS-22) were fabricated and characterized to assess the impact of $\mathrm{ThO}_{2}$ on durability within the Frit 418 - SB6 glass forming region. Table 2 summarizes the targeted compositions of these Th-containing glasses. The five glasses were based on a nominal projection of SB6 updated using the analysis of the SB6 qualification sample (Fox and Edwards 2010). The five Th-containing glasses targeted waste loadings of $32-40 \%$ in $2 \%$ increments.

All of the Frit 418 - SB6 glasses were fabricated and characterized under the auspices of RW-0333P requirements (Raszewski 2009). Density measurements were performed using SRNL procedure "Glass Density Using the Mettler AT400 (or Equivalent) Balance" (L29 Manual, ITS-057). Duplicate density measurements were performed on each glass. 
Table 1. Target Glass Compositions for SB6 Variability Study Glasses (wt\%).

(Johnson and Edwards 2010)

\begin{tabular}{|c|c|c|c|c|c|c|c|c|c|}
\hline Glass ID & "SB6VS-01 & SB6VS-02 & 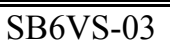 & "SB6VS-04 & "SB6VS-05 & "SB6VS-06 & $\begin{array}{c}\text { SB6VS-07 } \\
\end{array}$ & "SB6VS-08 & 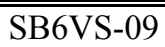 \\
\hline $\mathrm{Al}_{2} \mathrm{O}_{3}$ & 10.03 & 9.79 & 10.35 & 9.76 & 10.53 & 9.81 & 10.53 & 8.46 & 8.46 \\
\hline $\mathrm{B}_{2} \mathrm{O}_{3}$ & 5.12 & 5.12 & 5.12 & 5.12 & 5.12 & 5.12 & 5.12 & 5.12 & 5.12 \\
\hline $\mathrm{BaO}$ & 0.05 & 0.05 & 0.05 & 0.02 & 0.05 & 0.02 & 0.02 & 0.02 & 0.05 \\
\hline $\mathrm{CaO}$ & 0.28 & 0.73 & 0.28 & 0.73 & 0.28 & 0.73 & 0.28 & 0.28 & 0.73 \\
\hline $\mathrm{Ce}_{2} \mathrm{O}_{3}$ & 0.08 & 0.08 & 0.08 & 0.03 & 0.08 & 0.03 & 0.03 & 0.03 & 0.08 \\
\hline $\mathrm{Cr}_{2} \mathrm{O}_{3}$ & 0.05 & 0.05 & 0.05 & 0.02 & 0.05 & 0.02 & 0.02 & 0.02 & 0.05 \\
\hline $\mathrm{CuO}$ & 0.04 & 0.04 & 0.04 & 0.01 & 0.04 & 0.01 & 0.01 & 0.01 & 0.04 \\
\hline $\mathrm{Fe}_{2} \mathrm{O}_{3}$ & 9.66 & 9.66 & 7.81 & 9.66 & 7.93 & 7.81 & 7.81 & 9.66 & 9.66 \\
\hline $\mathrm{K}_{2} \mathrm{O}$ & 0.03 & 0.03 & 0.03 & 0.01 & 0.03 & 0.01 & 0.01 & 0.01 & 0.03 \\
\hline $\mathrm{La}_{2} \mathrm{O}_{3}$ & 0.04 & 0.04 & 0.04 & 0.01 & 0.04 & 0.01 & 0.01 & 0.01 & 0.04 \\
\hline $\mathrm{Li}_{2} \mathrm{O}$ & 5.12 & 5.12 & 5.12 & 5.12 & 5.12 & 5.12 & 5.12 & 5.12 & 5.12 \\
\hline $\mathrm{MgO}$ & 0.50 & 0.06 & 0.06 & 0.06 & 0.06 & 0.06 & 0.50 & 0.06 & 0.50 \\
\hline $\mathrm{MnO}$ & 2.25 & 2.25 & 2.73 & 2.73 & 2.73 & 2.25 & 2.25 & 2.25 & 2.73 \\
\hline $\mathrm{Na}_{2} \mathrm{O}$ & 13.73 & 13.73 & 13.73 & 13.73 & 15.76 & 15.76 & 15.50 & 15.68 & 14.16 \\
\hline $\mathrm{NiO}$ & 0.86 & 0.86 & 1.26 & 1.26 & 0.86 & 0.86 & 1.26 & 1.26 & 1.26 \\
\hline $\mathrm{P}_{2} \mathrm{O}_{5}$ & 0.17 & 0.17 & 0.17 & 0.06 & 0.17 & 0.06 & 0.06 & 0.06 & 0.17 \\
\hline $\mathrm{PbO}$ & 0.01 & 0.01 & 0.01 & 0.00 & 0.01 & 0.00 & 0.00 & 0.00 & 0.01 \\
\hline $\mathrm{SO}_{4}$ & 0.62 & 0.38 & 0.62 & 0.38 & 0.38 & 0.62 & 0.38 & 0.62 & 0.62 \\
\hline $\mathrm{SiO}_{2}$ & 49.21 & 49.63 & 49.63 & 49.21 & 49.21 & 49.63 & 49.63 & 49.21 & 49.63 \\
\hline $\mathrm{ThO}_{2}$ & 0.00 & 0.00 & 0.00 & 0.00 & 0.00 & 0.00 & 0.00 & 0.00 & 0.00 \\
\hline $\mathrm{TiO}_{2}$ & 0.00 & 0.66 & 0.66 & 0.00 & 0.00 & 0.00 & 0.00 & 0.66 & 0.00 \\
\hline $\mathrm{U}_{3} \mathrm{O}_{8}$ & 2.03 & 1.42 & 2.03 & 2.03 & 1.42 & 2.03 & 1.42 & 1.42 & 1.42 \\
\hline $\mathrm{ZnO}$ & 0.03 & 0.03 & 0.03 & 0.01 & 0.03 & 0.01 & 0.01 & 0.01 & 0.03 \\
\hline $\mathrm{ZrO}_{2}$ & 0.09 & 0.09 & 0.09 & 0.03 & 0.09 & 0.03 & 0.03 & 0.03 & 0.09 \\
\hline Total & 100.00 & 100.00 & 100.00 & 100.00 & 100.00 & 100.00 & 100.00 & 100.00 & 100.00 \\
\hline
\end{tabular}


Table 1. Target Glass Compositions for SB6 Variability Study Glasses (wt\%) - continued. (Johnson and Edwards 2010)

\begin{tabular}{|c|c|c|c|c|c|c|c|c|}
\hline & SB6VS-10 & SB6VS-11 & SB6VS-12 & SB6VS-13 & SB6VS-14 & SB6VS-15 & SB6VS-16 & SB6VS-17 \\
\hline $\mathrm{Al}_{2} \mathrm{O}_{3}$ & 8.46 & 10.53 & 8.57 & 8.47 & 9.00 & 9.53 & 10.06 & 10.59 \\
\hline $\mathrm{B}_{2} \mathrm{O}_{3}$ & 5.12 & 5.12 & 5.12 & 5.44 & 5.28 & 5.12 & 4.96 & 4.80 \\
\hline $\mathrm{BaO}$ & 0.02 & 0.02 & 0.05 & 0.03 & 0.03 & 0.03 & 0.04 & 0.04 \\
\hline $\mathrm{CaO}$ & 0.28 & 0.73 & 0.73 & 0.45 & 0.48 & 0.50 & 0.53 & 0.56 \\
\hline $\mathrm{Ce}_{2} \mathrm{O}_{3}$ & 0.03 & 0.03 & 0.08 & 0.05 & 0.05 & 0.05 & 0.06 & 0.06 \\
\hline $\mathrm{Cr}_{2} \mathrm{O}_{3}$ & 0.02 & 0.02 & 0.05 & 0.03 & 0.03 & 0.03 & 0.03 & 0.03 \\
\hline $\mathrm{CuO}$ & 0.01 & 0.01 & 0.04 & 0.02 & 0.03 & 0.03 & 0.03 & 0.03 \\
\hline $\mathrm{Fe}_{2} \mathrm{O}_{3}$ & 9.66 & 7.81 & 7.81 & 7.79 & 8.28 & 8.76 & 9.25 & 9.74 \\
\hline $\mathrm{K}_{2} \mathrm{O}$ & 0.01 & 0.01 & 0.03 & 0.02 & 0.02 & 0.02 & 0.02 & 0.02 \\
\hline $\mathrm{La}_{2} \mathrm{O}_{3}$ & 0.01 & 0.01 & 0.04 & 0.02 & 0.03 & 0.03 & 0.03 & 0.03 \\
\hline $\mathrm{Li}_{2} \mathrm{O}$ & 5.12 & 5.12 & 5.12 & 5.44 & 5.28 & 5.12 & 4.96 & 4.80 \\
\hline $\mathrm{MgO}$ & 0.50 & 0.50 & 0.50 & 0.25 & 0.26 & 0.28 & 0.29 & 0.31 \\
\hline $\mathrm{MnO}$ & 2.73 & 2.73 & 2.25 & 2.21 & 2.35 & 2.49 & 2.63 & 2.77 \\
\hline $\mathrm{Na}_{2} \mathrm{O}$ & 14.38 & 14.49 & 15.76 & 14.02 & 14.39 & 14.77 & 15.14 & 15.52 \\
\hline $\mathrm{NiO}$ & 0.86 & 0.86 & 1.26 & 0.94 & 1.00 & 1.06 & 1.12 & 1.18 \\
\hline $\mathrm{P}_{2} \mathrm{O}_{5}$ & 0.06 & 0.06 & 0.17 & 0.10 & 0.11 & 0.11 & 0.12 & 0.13 \\
\hline $\mathrm{PbO}$ & 0.00 & 0.00 & 0.01 & 0.01 & 0.01 & 0.01 & 0.01 & 0.01 \\
\hline $\mathrm{SO}_{4}$ & 0.38 & 0.62 & 0.38 & 0.45 & 0.48 & 0.50 & 0.53 & 0.56 \\
\hline $\mathrm{SiO}_{2}$ & 49.63 & 49.21 & 49.21 & 52.37 & 50.90 & 49.42 & 47.94 & 46.46 \\
\hline $\mathrm{ThO}_{2}$ & 0.00 & 0.00 & 0.00 & 0.00 & 0.00 & 0.00 & 0.00 & 0.00 \\
\hline $\mathrm{TiO}_{2}$ & 0.66 & 0.66 & 0.66 & 0.29 & 0.31 & 0.33 & 0.35 & 0.36 \\
\hline $\mathrm{U}_{3} \mathrm{O}_{8}$ & 2.03 & 1.42 & 2.03 & 1.53 & 1.63 & 1.72 & 1.82 & 1.91 \\
\hline $\mathrm{ZnO}$ & 0.01 & 0.01 & 0.03 & 0.02 & 0.02 & 0.02 & 0.02 & 0.02 \\
\hline $\mathrm{ZrO}_{2}$ & 0.03 & 0.03 & 0.09 & 0.05 & 0.06 & 0.06 & 0.06 & 0.07 \\
\hline Total & 100.00 & 100.00 & 100.00 & 100.00 & 100.00 & 100.00 & 100.00 & 100.00 \\
\hline
\end{tabular}


Table 2. Target Glass Compositions for the Supplemental $\mathrm{ThO}_{2}$-Containing SB6 Variability Study Glasses (wt\%). (Johnson and Edwards 2010)

\begin{tabular}{|c|c|c|c|c|c|}
\hline & SB6VS-18 & SB6VS-19 & SB6VS-20 & SB6VS-21 & SB6VS-22 \\
\hline $\mathrm{Al}_{2} \mathrm{O}_{3}$ & 8.12 & 8.62 & 9.13 & 9.64 & 10.14 \\
\hline $\mathrm{B}_{2} \mathrm{O}_{3}$ & 5.44 & 5.28 & 5.12 & 4.96 & 4.80 \\
\hline $\mathrm{BaO}$ & 0.04 & 0.04 & 0.05 & 0.05 & 0.05 \\
\hline $\mathrm{CaO}$ & 0.44 & 0.47 & 0.49 & 0.52 & 0.55 \\
\hline $\mathrm{Ce}_{2} \mathrm{O}_{3}$ & 0.06 & 0.07 & 0.07 & 0.08 & 0.08 \\
\hline $\mathrm{Cr}_{2} \mathrm{O}_{3}$ & 0.04 & 0.04 & 0.04 & 0.04 & 0.05 \\
\hline $\mathrm{CuO}$ & 0.03 & 0.04 & 0.04 & 0.04 & 0.04 \\
\hline $\mathrm{Fe}_{2} \mathrm{O}_{3}$ & 7.51 & 7.98 & 8.45 & 8.92 & 9.39 \\
\hline $\mathrm{K}_{2} \mathrm{O}$ & 0.03 & 0.03 & 0.03 & 0.03 & 0.03 \\
\hline $\mathrm{La}_{2} \mathrm{O}_{3}$ & 0.03 & 0.04 & 0.04 & 0.04 & 0.04 \\
\hline $\mathrm{Li}_{2} \mathrm{O}$ & 5.44 & 5.28 & 5.12 & 4.96 & 4.80 \\
\hline $\mathrm{MgO}$ & 0.24 & 0.26 & 0.27 & 0.29 & 0.31 \\
\hline $\mathrm{MnO}$ & 2.14 & 2.27 & 2.40 & 2.54 & 2.67 \\
\hline $\mathrm{Na}_{2} \mathrm{O}$ & 13.69 & 14.05 & 14.40 & 14.76 & 15.12 \\
\hline $\mathrm{NiO}$ & 0.92 & 0.97 & 1.03 & 1.09 & 1.14 \\
\hline $\mathrm{P}_{2} \mathrm{O}_{5}$ & 0.14 & 0.15 & 0.16 & 0.16 & 0.17 \\
\hline $\mathrm{PbO}$ & 0.01 & 0.01 & 0.01 & 0.01 & 0.01 \\
\hline $\mathrm{SO}_{4}$ & 0.43 & 0.46 & 0.49 & 0.51 & 0.54 \\
\hline $\mathrm{SiO}_{2}$ & 52.35 & 50.88 & 49.40 & 47.92 & 46.44 \\
\hline $\mathrm{ThO}_{2}$ & 1.01 & 1.07 & 1.14 & 1.20 & 1.26 \\
\hline $\mathrm{TiO}_{2}$ & 0.29 & 0.31 & 0.33 & 0.35 & 0.37 \\
\hline $\mathrm{U}_{3} \mathrm{O}_{8}$ & 1.50 & 1.59 & 1.68 & 1.78 & 1.87 \\
\hline $\mathrm{ZnO}$ & 0.02 & 0.02 & 0.02 & 0.03 & 0.03 \\
\hline $\mathrm{ZrO}_{2}$ & 0.07 & 0.08 & 0.08 & 0.09 & 0.09 \\
\hline Total & 100.00 & 100.00 & 100.00 & 100.00 & 100.00 \\
\hline
\end{tabular}


The density results for the SB6 Variability Study glasses and the SRM1826 standard (a NIST traceable standard glass) are shown in Table 3. Each SB6VS glass was measured twice (two density measurements on the same bulk sample) while the SRM1826 standards, dispersed among the SB6VS glasses, were only measured once. Each standard measurement was on a different sample (i.e., 10 different samples of the SRM1826 standard were used during the density measurements). The results for the SRM1826 standard indicate no significant issues with the measurement technique. More specifically, the reported density and 99\% uncertainty of the SRM1826 glass is $2.549382 \pm 0.000039$ $\mathrm{g} / \mathrm{cm}^{3}$ (NIST 1993). The average measured density in this testing for this standard glass was 2.5495 $\mathrm{g} / \mathrm{cm}^{3}$ (a difference of less than $0.00012 \mathrm{~g} / \mathrm{cm}^{3}$ ). The results in Table 3 provide insight into the repeatability of the density measurements as well as an indicator of the lack of bias of these data.

Table 3. Measured Densities of Frit 418 - SB6 Variability Study Glasses.

\begin{tabular}{|c|c|c|c|c|c||}
\hline Glass & Description & WL & $\begin{array}{c}\text { Read \#1 } \\
\left(\mathbf{g} / \mathbf{c m}^{\mathbf{3}}\right)\end{array}$ & $\begin{array}{c}\text { Read \#2 } \\
\left(\mathbf{g} / \mathbf{c m}^{\mathbf{3}} \mathbf{)}\right.\end{array}$ & $\begin{array}{c}\text { Average Density } \\
\left(\mathbf{g} / \mathbf{c m}^{\mathbf{3}} \mathbf{)}\right.\end{array}$ \\
\hline & & & & & \\
\hline SRM1826 & Standard & - & 2.5495 & - & 2.5495 \\
\hline SB6VS-01 & EV & 36 & 2.6459 & 2.6459 & 2.6459 \\
\hline SB6VS-02 & EV & 36 & 2.6441 & 2.6441 & 2.6441 \\
\hline SB6VS-03 & EV & 36 & 2.6398 & 2.6408 & 2.6403 \\
\hline SB6VS-04 & EV & 36 & 2.6562 & 2.6558 & 2.6560 \\
\hline SB6VS-05 & EV & 36 & 2.6309 & 2.6309 & 2.6309 \\
\hline SB6VS-06 & EV & 36 & 2.6397 & 2.6402 & 2.6400 \\
\hline SRM1826 & Standard & - & 2.5487 & - & 2.5487 \\
\hline SB6VS-07 & EV & 36 & 2.6263 & 2.6282 & 2.6273 \\
\hline SB6VS-08 & EV & 36 & 2.6549 & 2.6549 & 2.6549 \\
\hline SB6VS-09 & EV & 36 & 2.6645 & 2.6645 & 2.6645 \\
\hline SRM1826 & Standard & - & 2.5487 & - & 2.5487 \\
\hline SB6VS-10 & EV & 36 & 2.6669 & 2.6689 & 2.6679 \\
\hline SB6VS-11 & EV & 36 & 2.6233 & 2.6222 & 2.6228 \\
\hline SB6VS-12 & EV & 36 & 2.6618 & 2.6618 & 2.6618 \\
\hline SB6VS-13 & Centroid & 32 & 2.6167 & 2.6176 & 2.6172 \\
\hline SB6VS-14 & Centroid & 34 & 2.6333 & 2.6314 & 2.6324 \\
\hline SB6VS-15 & Centroid & 36 & 2.6379 & 2.6397 & 2.6388 \\
\hline SRM1826 & Standard & - & 2.5497 & - & 2.5497 \\
\hline SB6VS-16 & Centroid & 38 & 2.6585 & 2.6585 & 2.6585 \\
\hline SB6VS-17 & Centroid & 40 & 2.6664 & 2.6664 & 2.6664 \\
\hline SRM1826 & Standard & - & 2.5496 & - & 2.5496 \\
\hline SB6VS-18 & Centroid & 32 & 2.6463 & 2.6454 & 2.6459 \\
\hline SB6VS-19 & Centroid & 34 & 2.6541 & 2.6572 & 2.6557 \\
\hline SB6VS-20 & Centroid & 36 & 2.6756 & 2.6709 & 2.6733 \\
\hline SRM1826 & Standard & - & 2.5501 & - & 2.5501 \\
\hline SB6VS-21 & Centroid & 38 & 2.6839 & 2.6855 & 2.6847 \\
\hline SB6VS-22 & Centroid & 40 & 2.7008 & 2.7004 & 2.7006 \\
\hline SRM1826 & Standard & - & 2.5502 & - & 2.5502 \\
\hline & & & & & \\
\hline
\end{tabular}




\subsection{RESULTS AND DISCUSSION}

In addition to interest in the waste loading (WL) versus density relationship, two sources of variation in the densities at each of the WLs are also of interest to this study: (1) the repeatability of the measurement process utilized for assessing glass density (i.e., how repeatable is the density measurement for a specific glass) and (2) changes in density from one glass to another (both representing the same WL) due to compositional differences in sludge (e.g., with and without $\mathrm{ThO}_{2}$ ). The sources of variation are investigated in Figure 1, which plots the density values grouped by Glass ID within \%WL. With respect to the issue of repeatability of the measurements for a given glass, the overlap (or small variation) of the replicate data demonstrates that the density measurements are very reproducible. With respect to the second source of variation (i.e., compositional differences due to sludge variation), the data indicate that the variation resulting from sludge differences (i.e., sludge EVs at a fixed WL with Frit 418)) is larger than that associated with the repeatability of the density measurement.

Since the density of interest is the true density of the glass produced by the Defense Waste Processing Facility (DWPF), the replication error (the variation due to the measurement process) for a single glass may be considered as a nuisance factor while the differences in the densities of the glass from one SME batch to the glass from another SME batch must be understood. 


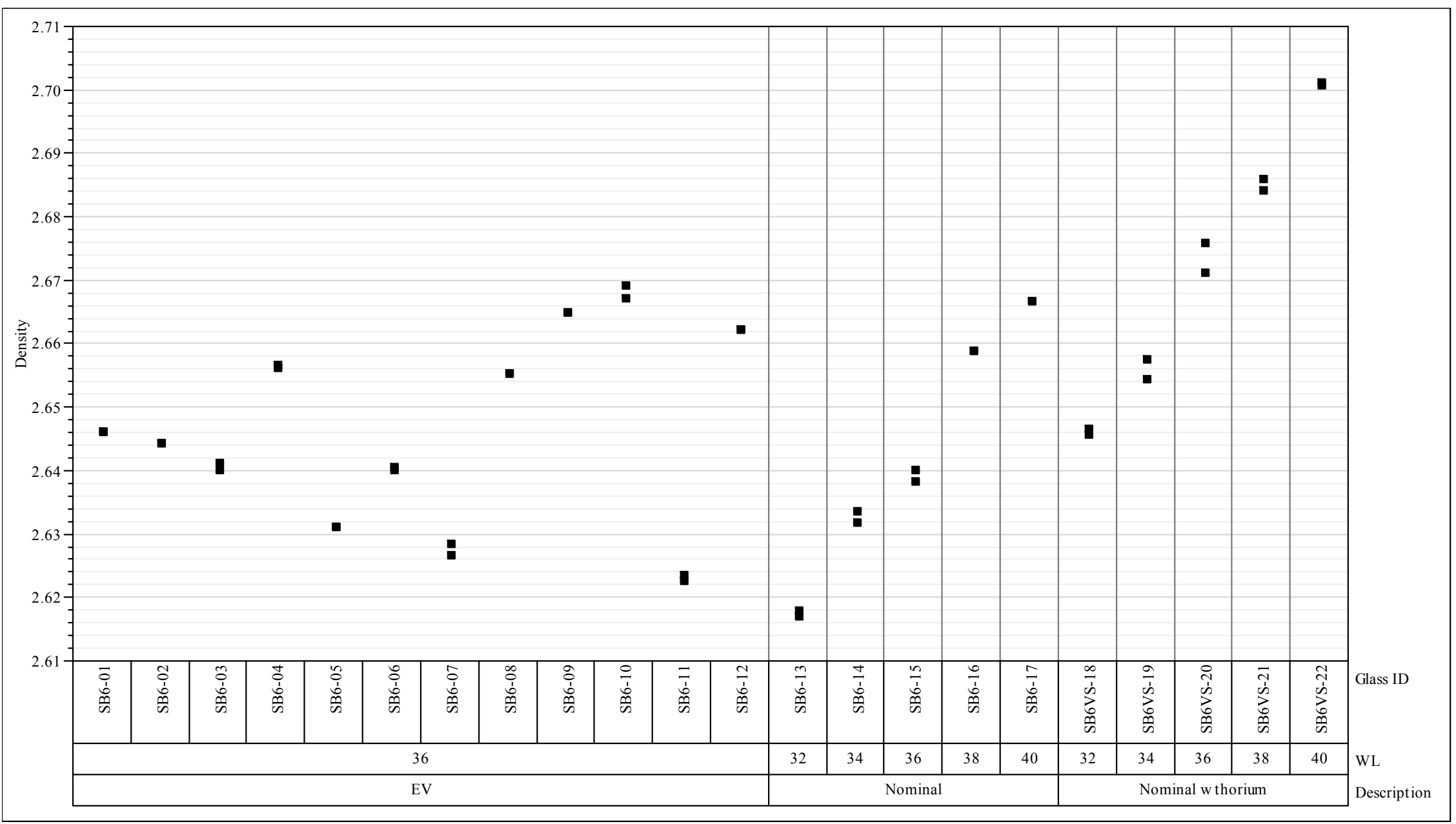

Figure 1. Densities by Glass ID Grouped by \%WL and Type of Sludge Composition. 
To that end, the replicate density measurements for each glass are averaged giving the results provided in Table 4. These data will be used in the regression of density on \%WL to more adequately represent the information available to fit this linear model. Thus, in assessing the scatter about the fitted line (i.e., the residual errors), the standard deviation estimated for these errors at a given \%WL will more appropriately represent the variation in densities due to compositional effects. The JMP ${ }^{3}$ output from this modeling effort is provided in Figure 2.

Table 4. Average Measured Densities of Frit 418 - SB6 Glasses.

\begin{tabular}{|c|c|c|c|c|}
\hline Description & $\mathbf{W L}$ & Glass ID & $\begin{array}{c}\text { Number of } \\
\text { Measurements }\end{array}$ & $\begin{array}{c}\text { Mean } \\
\left(\text { Density }\left(\mathrm{g} / \mathrm{cm}^{3}\right)\right)\end{array}$ \\
\hline $\mathrm{EV}$ & 36 & SB6-01 & 2 & 2.6459 \\
\hline EV & 36 & SB6-02 & 2 & 2.6441 \\
\hline EV & 36 & SB6-03 & 2 & 2.6403 \\
\hline $\mathrm{EV}$ & 36 & SB6-04 & 2 & 2.6560 \\
\hline $\mathrm{EV}$ & 36 & SB6-05 & 2 & 2.6309 \\
\hline EV & 36 & SB6-06 & 2 & 2.6400 \\
\hline EV & 36 & SB6-07 & 2 & 2.6273 \\
\hline $\mathrm{EV}$ & 36 & SB6-08 & 2 & 2.6549 \\
\hline EV & 36 & SB6-09 & 2 & 2.6645 \\
\hline $\mathrm{EV}$ & 36 & SB6-10 & 2 & 2.6679 \\
\hline $\mathrm{EV}$ & 36 & SB6-11 & 2 & 2.6228 \\
\hline $\mathrm{EV}$ & 36 & SB6-12 & 2 & 2.6618 \\
\hline Nominal & 32 & SB6-13 & 2 & 2.6172 \\
\hline Nominal & 34 & SB6-14 & 2 & 2.6324 \\
\hline Nominal & 36 & SB6-15 & 2 & 2.6388 \\
\hline Nominal & 38 & SB6-16 & 2 & 2.6585 \\
\hline Nominal & 40 & SB6-17 & 2 & 2.6664 \\
\hline Nominal w thorium & 32 & SB6VS-18 & 2 & 2.6459 \\
\hline Nominal w thorium & 34 & SB6VS-19 & 2 & 2.6557 \\
\hline Nominal w thorium & 36 & SB6VS-20 & 2 & 2.6733 \\
\hline Nominal w thorium & 38 & SB6VS-21 & 2 & 2.6847 \\
\hline Nominal w thorium & 40 & SB6VS-22 & 2 & 2.7006 \\
\hline
\end{tabular}

Figure 2 shows the relationship between density and WL for the nominal SB6 Variability Study glasses (without $\mathrm{ThO}_{2}$ - blue line in Figure 2) and the supplemental Th-containing glasses (orange line in Figure 2). ${ }^{4}$ As expected, as WL increases the density for both series of SB6 glasses increases. The data also indicate an increase in density (at a fixed WL) between glasses without $\mathrm{ThO}_{2}$ and those with $\mathrm{ThO}_{2}$. The addition of $\mathrm{ThO}_{2}$ appears to add approximately 0.03 to $0.05 \mathrm{~g} / \mathrm{cm}^{3}$ over the WLs of interest in this study.

\footnotetext{
${ }^{3}$ JMP Version 7.0.2, SAS Institute, Inc., Cary, NC.

${ }^{4}$ Figure 2 does not include the SB6VS glasses based on extreme vertices - only the nominal SB6 projections with and without $\mathrm{ThO}_{2}$ are used in this assessment.
} 


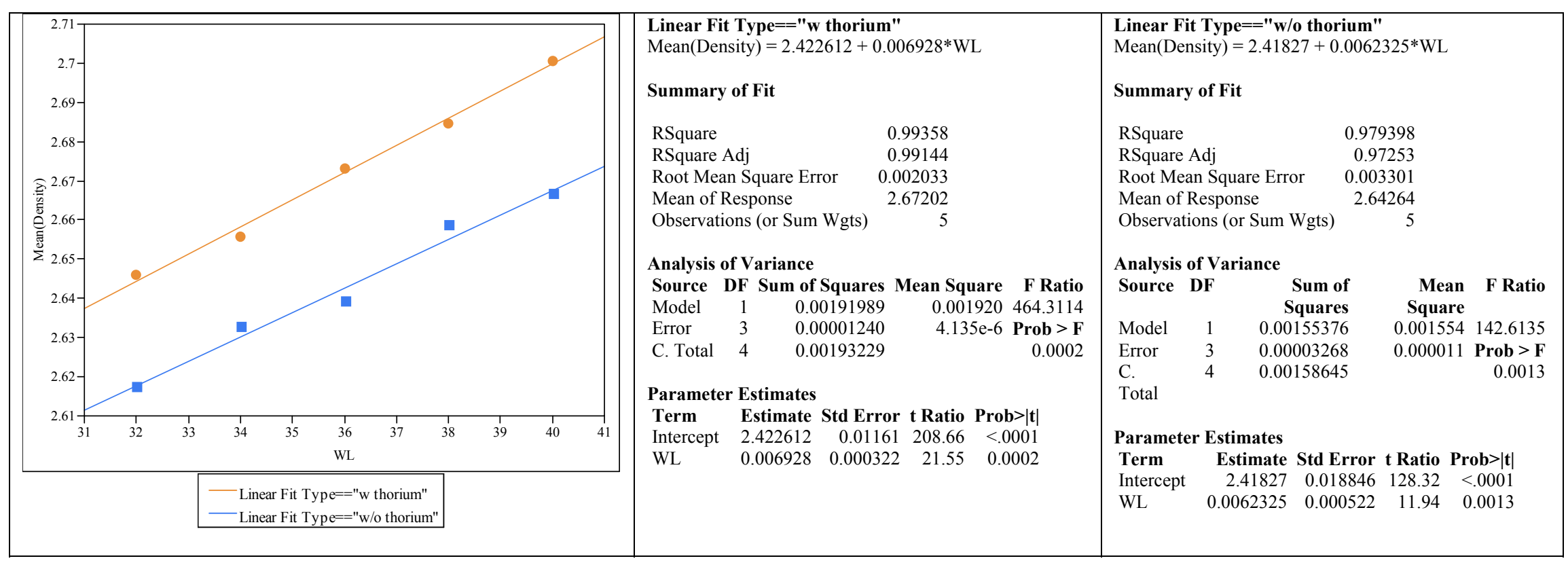

Figure 2. Density as a Function of Waste Loading for the Nominal Frit 418 - SB6 Variability Study Glasses.

(Nominal Sludge Compositions with Thorium ( $($ ) and without Thorium (•)) 
It is recognized that these linear regressions are based on two nominal SB6 projections (one with and one without $\mathrm{ThO}_{2}$ ) but without accounting for potential waste composition variation (with the exception of variation due to the introduction of $\mathrm{ThO}_{2}$ ). To bound the density versus WL relationship for the SB6 glass system one would appeal to the upper fitted line corresponding to the nominal sludge projection with $\mathrm{ThO}_{2}$. Using the approach of Miller (1986), as was used by Edwards and Peeler (2009) to support SB5, leads to an upper tolerance limit (UTL) for $100\left(1-\alpha_{0}\right) \%$ of all density values of the SB6 glasses with $\mathrm{ThO}_{2}$ at a confidence of $100(1-\alpha) \%$ for each and every WL within the interval from 32 to $40 \%$ :

$$
\mathrm{UTL} \rho_{\mathrm{i}}=\mathrm{b}+\mathrm{m} \cdot \mathrm{WL}_{\mathrm{i}}+\mathrm{s}\left\{\sqrt{\mathrm{pF} \mathrm{F}_{\alpha}(\mathrm{p}, \mathrm{n}-\mathrm{p})} \sqrt{\underline{\mathrm{c}}_{0}\left(\mathbf{X}^{\mathrm{T}} \mathbf{X}\right)^{-1} \underline{\mathrm{c}}_{0}{ }^{\mathrm{T}}}+\mathrm{z}_{1-\alpha_{0}} \sqrt{\frac{\mathrm{n}-\mathrm{p}}{\chi_{\alpha / 2, \mathrm{n}-\mathrm{p}}^{2}}}\right\}
$$

where

- UTL $\rho_{\imath}$ equals the upper tolerance interval for the glass density at $\mathrm{WL}_{\mathrm{i}}$,

- the estimated slope and intercept of the fitted model are $\mathrm{m}$ and $\mathrm{b}$, respectively, (where $\mathrm{m}=$ 0.006928 and $b=2.422612$ ),

- $s$ is the root mean square error (RMSE) for the fitted model (the value is given by 0.002033 ),

- $\mathrm{F}_{\alpha}(\mathrm{p}, \mathrm{n}-\mathrm{p})$ is the $\mathrm{F}$ statistic, which depends on $\mathrm{n}$ (i.e., the number of data points on which this p-parameter model is based) and the desired confidence level as represented by $(1-\alpha) 100 \%$,

- the inverse product-moment matrix is represented by $\left(\mathbf{X}^{\mathrm{T}} \mathbf{X}\right)^{-1}$ where the product moment matrix contains information describing the data for the independent variable (i.e., the WLs) used to generate the regression equation (the WL values of this matrix are given as part of the information of Table 3),

- $\underline{\mathrm{c}}_{0}$ is the vector, $\left[1 \mathrm{WL}_{\mathrm{i}}\right]$, containing the $\mathrm{WL}_{\mathrm{i}}$,

- $\mathrm{z}_{1-\alpha_{0}}$ represents the one-sided $100\left(1-\alpha_{0}\right) \%$ percentile point from the standard normal distribution representing the $1-\alpha_{0}$ fraction of the model predictions to be covered, and

- $\chi_{\alpha / 2, \mathrm{n}-\mathrm{p}}^{2}$ represents the lower (i.e., $\left.\alpha / 2\right)$ percentile point of the $\chi^{2}$ distribution with $(\mathrm{n}-\mathrm{p})$ degrees of freedom.

However, using equation (1) to bound the density for the SB6 glass system based solely on the results from fitting the upper regression line of Figure 2, which corresponds to the nominal sludge projection with $\mathrm{ThO}_{2}$, would be inadequate in capturing the impact of the variation in sludge composition on density. To quantify this variation, the densities of all of the glasses (both nominal and EV-based) representing a WL of $36 \%$ are utilized. Figure 3 provides a histogram and descriptive statistics for these data. From this figure, the standard deviation of the density values for the glasses at $36 \% \mathrm{WL}$ is given by $0.01568 \mathrm{~g} / \mathrm{cm}^{3}$. Using this value in the computation of equation (1) instead of the RMSE value of $0.002033 \mathrm{~g} / \mathrm{cm}^{3}$ from Figure 2 provides a more representative UTL for the relationship between density and WL for the SB6 glass system. 


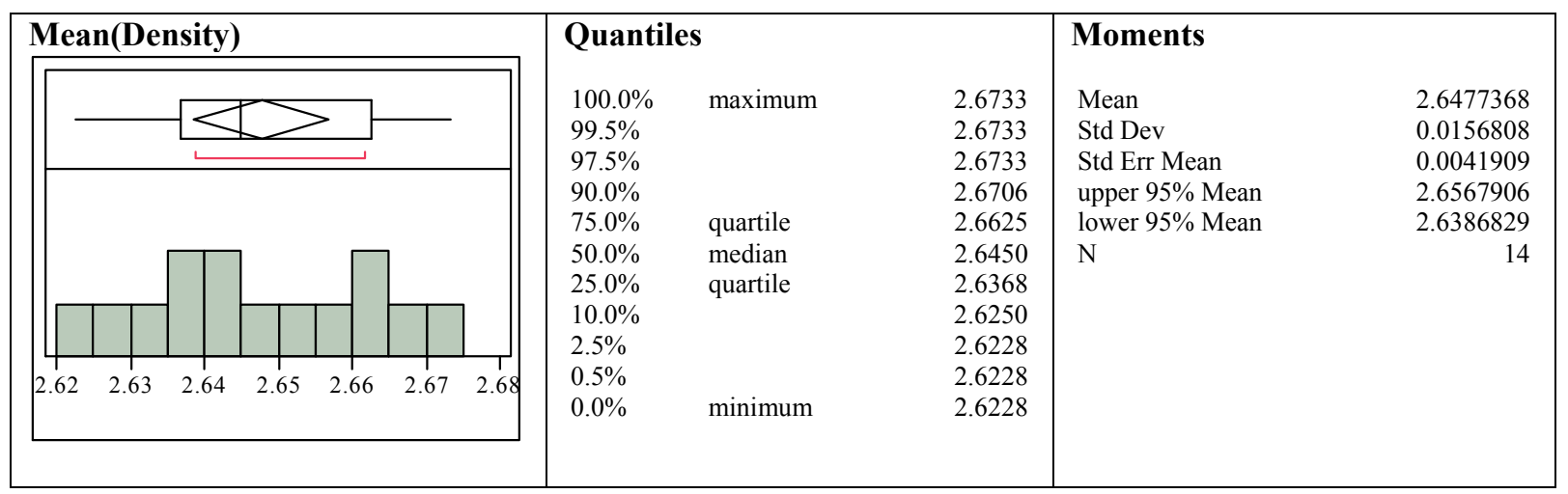

Figure 3. Histogram and Descriptive Statistics for the Densities of SB6 VS Glasses at WL of $36 \%$.

Based upon the information in Figure 2 and Figure 3 and utilizing equation (1), a 99\% upper tolerance limit (using 0.0156806 for the value of $\mathrm{s}$ in the equation) was developed to bound at $99 \%$ confidence the densities of SB6 glasses at WL from 32 to $40 \%$. Table 5 summarizes the predicted (mean) density as a function of WL for the linear model, and the 99/99 UTL. The data table reveals that there is a $99 \%$ confidence that as long as the WLs are no greater than $38 \%$, then the densities of $99 \%$ of the resulting SB6 glass will be no greater than $2.823 \mathrm{~g} / \mathrm{cm}^{3}$. Utilizing a $99 / 99$ UTL will add an additional layer of conservatism with respect to the bounding density (at $38 \% \mathrm{WL}$ ) to be used in the fissile loading spreadsheet.

Table 5. Predicted Densities as a Function of WL for the Linear Fit and 99/99 UTL.

\begin{tabular}{||c|c|c||}
\hline WL & $\begin{array}{c}\text { Predicted Mean } \\
\text { Density }\left(\mathbf{g} / \mathbf{c m}^{\mathbf{3}}\right)\end{array}$ & 99/99 UTL \\
\hline 32 & 2.644 & 2.809 \\
\hline 34 & 2.658 & 2.795 \\
\hline 36 & 2.672 & 2.797 \\
\hline 38 & 2.686 & 2.823 \\
\hline 40 & 2.700 & 2.865 \\
\hline
\end{tabular}

It is recommended that DWPF Engineering utilize the 99/99 UTL density value at 38\% WL $(2.823$ $\mathrm{g} / \mathrm{cm}^{3}$ ) as a bounding density for SB6 glasses to assess the fissile concentration in this glass system. That is, $2.823 \mathrm{~g} / \mathrm{cm}^{3}$ is recommended as a key (and fixed) input into the fissile concentration spreadsheet. 


\subsection{SUMMARY}

DOE-SR previously provided direction to SRR to maintain fissile concentration in glass below 897 $\mathrm{g} / \mathrm{m}^{3}$. In support of the guidance, SRNL provided a technical basis and a supporting Microsoft Excel spreadsheet for the evaluation of fissile loading in SB5 glass based on the Fe concentration in glass as determined by the measurements from the SME acceptability analysis. SRR has since requested that SRNL provide the necessary information to allow SRR to update the inputs to the Excel spreadsheet so that it may be used to maintain fissile concentration in glass below $897 \mathrm{~g} / \mathrm{m}^{3}$ during the processing of SB6.

One of the primary inputs into the fissile loading spreadsheet includes a bounding density for SB6 glasses. Based on the measured density data of select SB6 variability study glasses, SRNL recommends that SRR utilize the $99 / 99$ UTL density value at $38 \% \mathrm{WL}\left(2.823 \mathrm{~g} / \mathrm{cm}^{3}\right)$ as a bounding density for SB6 glasses to assess the fissile concentration in this glass system. That is, $2.823 \mathrm{~g} / \mathrm{cm}^{3}$ is recommended as a key (and fixed) input into the fissile concentration spreadsheet for SB6 processing. It should be noted that no changes are needed to the underlying structure of the Excel spreadsheet to support fissile assessments for SB6. However, SRR should update the key inputs based on fissile and Fe concentrations reported from the SB6 WAPS sample. 


\subsection{REFERENCES}

Bannochie, CJ. 2010. Tank 40 Final SB6 Chemical Characterization Results, U.S. Department of Energy Report SRNL-STI--2010-00441, Revision 0, Savannah River National Laboratory, Aiken, South Carolina.

Fox, K. M. and T. B. Edwards. 2010. Impact of Thorium on Projected Operating Windows for Sludge Batch 6 with Frit 418, U.S. Department of Energy Report SRNL-L3100--2010-0094, Revision 0, Savannah River National Laboratory, Aiken, South Carolina.

Johnson, FC and TB Edwards. 2010. Sludge Batch 6 Variability Study with Frit 418, U.S. Department of Energy Report SRNL-STI-2010-00242, Revision 0, Savannah River National Laboratory, Aiken, South Carolina.

L29 Manual, ITS-0057. Glass Density Using the Mettler AT400 (Or Equivalent) Balance, Savannah River National Laboratory, Aiken, SC, ITS-0057, Latest Revision.

Miller, RG. 1989. Simultaneous Statistical Inference, Second Edition, Springer-Verlag, New York.

Peeler, DK and TB Edwards. 2009. Estimation of Fissile Mass Loadings from Iron Concentrations in SB5 Glasses, SRNL-TR-2009-00258, Revision 0, Savannah River National Laboratory, Aiken, SC.

Raszewski, FC. 2009. Sludge Batch 6 Glass Variability Studies: Task Technical and Quality Assurance Plan, U.S. Department of Energy Report SRNL-STI-2009-00156, Revision 0, Savannah River National Laboratory, Aiken, South Carolina.

NIST. 1993. "Certificate: Standard Reference Material 1826 - Soda-Lime Glass Density Standard," National Institute of Standards and Technology, Gaithersburg, MD, January 29, 1993. 


\section{Distribution:}
A.B. Barnes, 999-W
D.A. Crowley, 773-43A
S.D. Fink, 773-A
B.J. Giddings, 786-5A
C.C. Herman, 999-W
S.L. Marra, 773-A
F.M. Pennebaker, 773-42A
J.W. Amoroso, 999-W
C.J. Bannochie, 773-42
A.L. Billings, 999-W
J.M. Bricker, 704-27S
C.L. Crawford, 773-42A
T.B. Edwards, 999-W
H.H. Elder, 704-24S
T.L. Fellinger, 704-26S
K.M. Fox, 999-W
J.M. Gillam, 766-H
B.A. Hamm, 766-H
E.W. Holtzscheiter, 704-15S
J.F. Iaukea, 704-30S
P.R. Jackson, 703-46A
F.R. Johnson, 999-W
J.E. Occhipinti, 704-S
D.K. Peeler, 999-W
J.W. Ray, 704-S
H.B. Shah, 766-H
D.C. Sherburne, 704-S
A.V. Staub, 704-27S
M.E. Stone, 999-W
J.P. Vaughan, 773-41A
R.N. Hinds, 704-S 